\title{
Methodological Framework of Business Reengineering within Logistics System
}

\author{
Marina Čičin-Šain, Slavomir Vukmirović and Zvonko Čapko \\ Faculty of Economics and Business Administration Rijeka, University of Rijeka, Croatia
}

\begin{abstract}
Methodological scope of business reengineering is designed by using logistics information systems researches carried out in most highly developed countries. Methods of information system development are analysed from the business engineering point of view. The example of the information system development in the function of business reengineering describes the usage of the method of the system structural analysis in redesigning the process of transport of goods, which is critical for optimization of process of transport within the system of logistics. Based upon the analysis of the logistics system, business necessities and studies of information system development researches in certain companies in Germany and USA, some of significant factors of strategic development of logistics information systems have been defined.
\end{abstract}

Definition of critical factors of information system development and their mutual interaction intensity provides the guidelines for forming the methodological scope of business reengineering of the logistics system.

Keywords: business reengineering, logistics system, information system, sinergy, optimization.

\section{Introduction}

Logistics information system is directed towards gathering, processing and exchange of data and information relevant to management and performance of logistic acquisition activities, transport, storage and distribution of goods and services. System of logistics or company supply chain expands from acquisition of material from supplier to distribution of end products to their consumers.

The subject of research of logistics information system development is management of the flow of goods and information between participants in the logistics system on the basis of modern information technologies and computer-supported methods of information system development.

The need to speed up the changes in performance of business processes in logistics is significantly higher in relation to the traditional business systems where it was enough to plan the changes for a period of three, five and ten years. Considering the changing conditions in logistics, there is a need for more flexibility and adjustments. The capability of reconfiguration of relevant business processes and activities of system of logistics are critical in any moment in accordance to the changes in subject's environment within the system of logistics and logistics environment. Significant feature of gaining the flexibility and adaptation of logistics is a computer supported business reengineering.

The above mentioned refers to the base hypothesis of this study: the crucial factor of successful and efficient functioning of logistics system is business reengineering based upon the continuous and synergy implementation and usage of information technologies within the logistics system.

\section{Correlation of Information Technology, Business Reengineering and System of Logistics}

Replacing the old processes with new ones is called business process redesign. The term 
business process reengineering is also used. Information technology and business reengineering influence each other in two ways. First, business reengineering initiates development of business system computerization and introduction of new, improved information technologies when redesigning the computer systems incapable of functioning with existing maintenance. Those systems are called legacy systems, due to the fact that their value is too high in order to be removed, but they represent a burden for information system resources.

On the other hand, achievements in the area of information technology initiate inventiveness, creativeness and development as a reengineering foundation assumption. For example, object technologies are very important for integration of informatics and business technologies and they represent a powerful tool for redefining business processes. There are three fundamental components for applying business reengineering in the information system. Those techniques are known as triple $\mathrm{R}$ - Reverse Engineering, Restructuring and Reengineering. Those components can be used separately or together.

1. Reverse engineering is a result of business intelligence. When used in computerization, reverse engineering is a procedure of analysing the system in order to identify its elements and inner relations, as well as to create documentation on a higher level of abstraction than it used to be.

Reverse engineering is applied to the system when there is no need for preparation of new documentation. The starting point of reverse engineering is a program code, which is redesigned into documentation such as action diagram structural English (or pseudo-code) and presentation of the program flow. Such documentation allows consecutive redesign to even more abstract descriptions such as data flow diagrams and system flow presentation. Reverse engineering does not change systems - the tasks it performs, but has a goal to better understand the system, so the changes such as restructuring and reengineering could be made.

2. Restructuring is transforming the system to a different form, without changing its functionality. A good example of program transfer which has been written in the first years of computer science, when there were only several programming standards, was a structural form that consisted of hierarchically compiled parts, modules. As soon as the program was restructured, it caused reusage of circle, in a reverse form. As well as the reverse engineering, restructuring can be performed in reverse, through every phase of system life cycles. The result is a completely structured system - from planning to code programming.

3. Reengineering is a complete reshape/redesign of the system, with the goal of achieving the changes in its functionality. This does not represent the "no obligation" approach, because it does not completely ignore the knowledge of existing system. This knowledge is a result of the first initiative of reverse engineering. In that moment, the system is developed under usual environment. The term "restructuring engineering" is given to a process that follows the system life cycles under usual circumstances, at the time of commencing the same within the system.

The components of business engineering (triple R) can be applied separately or together, depending on the level of necessary changes. The relevant combination of components depends on the current condition of the system expressed in functional and technical quality. Picture 1 shows the diagram of influence of those two factors. Business environment defines the requests that should be fulfilled by logistics information system. The capability of fulfilling those requests defines the quality of system functionality where the system operation is checked.

\begin{tabular}{cc|c|c|}
\cline { 3 - 4 } \multicolumn{1}{c|}{$\begin{array}{c}\text { Business } \\
\text { request }\end{array}$} & $\begin{array}{c}\text { Reverse } \\
\text { engineering }\end{array}$ & $\begin{array}{c}\text { Reengineer. } \\
\text { unnecessary }\end{array}$ \\
\cline { 3 - 4 } & Variable & Reengineering & $\begin{array}{c}\text { Restructuring } \\
\text { engineering }\end{array}$ \\
\cline { 3 - 4 } & \multicolumn{2}{|c|}{$\begin{array}{c}\text { Variable } \\
\text { Technology }\end{array}$}
\end{tabular}

Table 1. Matrix representing the needs for business reengineering. 
The technology used by the system defines the way of system performance (system operation). Objective evaluation of necessities for business reengineering could be performed out of matrix of business requests relations given to business system and technologies that are most important for the business system (Table 1).

If the technology is stable and environment is variable, then reverse engineering will be performed followed by restructuring. The reverse engineering elaborated the documentation that provides restructuring performance. When the environment is variable, and the technology is stable, restructuring engineering will be performed. In that case, the system is compliant to modern technique, but it simply cannot perform properly. If technology and environment are both stable, as shown in the upper right quadrant of the scheme, then there is no need for reengineering. Such situation is present in supporting and operative activities and processes. According to the lower left quadrant of the scheme, when the business environment and technology are both variable, then there should be performed reengineering.

Vertical axis of the matrix relates to functionality and horizontal axis relates to technological quality. Functionality can be defined as a measure of influence to the information technologies on impact of the logistics system, and technological quality as a measure of level of information technology development used in logistics system $(7 ; 144)$. The functionality shows what the system is actually performing, and technological quality the way it is performed. Functionality can be measured and estimated on the basis of intensity of the usage of information technology in logistics systems. Research of informatization measurements in logistics processes $(2 ; 174)$, relates to the degree of logistics system informatization between 50 and $100 \%$ (for example: measurement of order management process which is $96 \%$, the warehouse management $89 \%$ ).

Analysing the results of research of logistics companies' informatization it can be concluded a parallel continuous development of technological and functional logistics system informatization component. The logistics companies continuously follow the development of the in- formation technologies from one side, and purchase new information technologies relevant to their business processes. On the other side, the percentage of business processes covered by computer applications is on high level of 50 to $100 \%$, which shows the transparency of logistics system for usage of information technologies $(2 ; 174)$. Continuous parallel development of functional and technological components of logistics system informatization shows a constant need for certain level of reengineering of logistics system. Development of information technology, whose components are crucially important for the efficiency of the logistics system, initiates reengineering of the logistics system.

This position contains logistics systems. The position of logistics system can be defined on the basis of technology used by the logistics system and dynamics of logistics environment. Considering the fact that base technology of logistics system is information technology and that the logistics environment is clearly dynamic, it can be concluded that logistics system should be moved to the lower left quadrant. This means that business reengineering is a significant factor in successful functioning of logistics system.

\section{Critical Factors of Information System Development From the Business Reengineering Point of View}

Business necessities of the logistics system are directional guidelines for development of information system towards planning and analysis "top-down" approach.

On the other hand, the approach to analysis of "bottom-up" identifies the critical factors of information system development that could support the achievement of the logistics system goals in the best possible manner. When defining the critical factors of information system development it has been used study of information system development (1); as a starting point, (10) in USA companies, established by Manager Information System Research Centre (MISRC) at Minnesota University and Society For Information Management (SIM). The study 
used Delphi method. Questionnaires contained 26 factors of information system development and were distributed to executive managers and managers of information departments of USA companies. Study demonstrated list of factors and results of research, as well as the comparative results of the research carried out in 1989.

Factors can be divided in four groups: information-technological support factors, inner efficiency factors, factors of business correlating and management support and factors of application development. According to the research, the managers are refocusing to factors of information-technological support, such as information infrastructure reactivity and distributed systems. The management support factors, such as planning of information system development, human resources and organisational learning comes second. It is obvious that the appearance of factors of computer-supported business reengineering is new in relation to the previous research and, as such, positioned among the two of the most important factors.

Analysing the stated factors of information system development, it is very important to acknowledge the intensity of the correlation. At a certain level all factors are mutually related, where the intensity of the relation is different between them. The strongest relations are inside previously stated group of factors. Upon identification of critical factors of strategic development of information system of logistics and critical relations between those factors, the sys- tem of strategic development factors of logistics information system are defined and, therefore, its methodological scope as well. Table 2 defines the critical factors of the development of logistics system.

Comparing the defined factors in study and Table 1 there can be established that between ten critical factors of logistics information system development factors six of them are new ones in relation to the research carried out in 1994, shown in study. Among the factors shown in Table 2, particularly significant factors are object technology and hypermedia applications. Object technologies are critical components of computer-supported business reengineering. Hypermedia applications are fundamental for establishing information systems between organisations.

Taking into consideration that factors of logistics information system development correlate, some of the most important features of factors synergy influence on logistics information system development are established and defined in Table 1. Most significant trends in logistics information system development pointed out by the factors configuration in Table 1 are:

1. In logistics information system development are used computer supported methods of business reengineering at all levels - strategic, tactical and operative.

\begin{tabular}{|l|c|}
\hline Factors of strategic development in logistics information system in 2000 & Level 1994. \\
\hline \hline Reactive information infrastructure & 1 \\
Computer-supported business reengineering & 2 \\
Development and management of distributed systems & 3 \\
Development and implementation of information architecture & 4 \\
Implementation and management of systems for group work support & 11 \\
Object technologies & $\mathrm{D}$ (out) \\
Integration of program for development of applicative software and & $\mathrm{N}$ (new) \\
method of strategic development of logistics information systems & $\mathrm{D}$ (out) \\
Systems for decision-making support and executive information systems & $\mathrm{N}$ (new) \\
Development and implementation of hypermedia applications & 20 \\
Outsourcing services of logistics information system development &
\end{tabular}

Table 2. Factors of strategic information system development in logistics companies. 
2. Object technologies, together with methods of fast hypermedia applications development create applications between companies and redirect the development of logistics information system from the level of each company involved in logistics system, according to the levels of flexible and adaptive information system between companies, whose operation is based upon the business reengineering (4).

\section{Designing Methodological Scope of Business Reengineering of Logistics Information System}

The purpose of the methodological business reengineering of logistics information system is correlation of the possibilities of information technology with business needs for logistics system.

Methodological scope should be used by executive and information management of logistics system subjects, as a management tool for logistics information system development in function of business needs $(3 ; 217)$. Methodological scope of business reengineering of logistics information system can be defined as a group of principles, directions and regulations for targeting of implementation process, building, modifying and usage of information system within logistics system business.

The configuration of the logistics information system development factors defined, on the ba- sis of research, demonstrated that the methodology of strategic development of information system development should be directed towards business reengineering in function of flexible and adaptive logistics system among companies. Figure 1 shows the system of critical factors of information technology development in function of business logistics system reengineering.

Critical factors of methodological scope of information development in function of business reengineering should be recognized as an integral set where they are firmly connected components. Synergy of object and hypermedia technologies create assumptions for fast development of applications among companies. Strategically oriented informatics education is in form of two-sided relations with object and hypermedia technology.

Critical factors of logistics information system development define the development guidelines for methodological scope of strategic development logistics information system. Figure 1 shows methodological framework of synergie development of information technolgy in function of dynamical optimization of logistics system.

Hypermedia technology supports gathering of relevant data where object technologies support their systematization from the problem situation point of view. Strategically oriented education in informatics enables human potentials
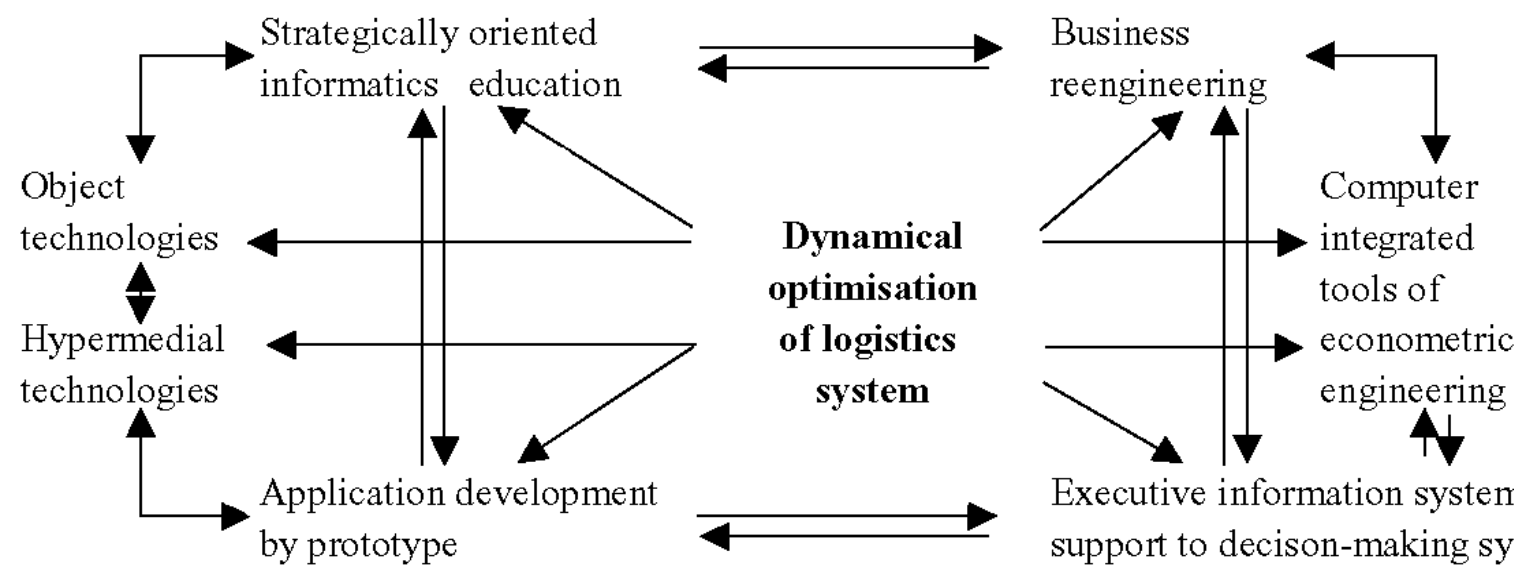

Executive information systems and support to decison-making systems

Fig. 1. Methodological framework of synergie development of information technology in function of dynamical optimization of logistics system. 
to creatively and innovatively use object and hypermedia technologies. Optimally, usage of hypermedia and object technology provides flexible and adaptive development of applications among companies, in accordance with the variations of environment and business goals inside and between participants of logistics system (4), (10).

In Table 3 the factors of strategic development of logistics information system are systematized according to the information system components. According to the definition, business process in logistics can be defined as a group of information processes, where the management and executive process of logistics system are entirely determined by the information process (6), (9). Therefore, the business process of logistics system can be systematized to information processes of gathering, systematization, exchange, reorganising, data processing and usage, and information in management and decision-making. Information process components are defined in the table header and mutually related, which means that there is a synergy effect with integrated functioning providing more successful results compared to the linear value of their separate factors.
Table 3 shows relative factors of business reengineering of logistics system according to the components of information process. Influences are indicated as " 1 ".

Taking into consideration that there is a synergy effect of information process components, the influence of business reengineering factors will depend on their mutual relations and level of synergy influence strength (8). Synergy influence of business reengineering factors can be analysed through a mathematical model.

Analysis of logistics system shows that logistic processes are based upon gathering, data processing and data and information exchange within and between the organisational units at the company level, as well as between the company and the logistics environments. All business activities of logistics system can be supported by the computer applications and the base result (product, service) of business process of logistics system is an informatization $(11 ; 133)$. Logistics system should function on the basis of information organisation formed in such way that logistics services could create and distribute towards purchasers in prompt

\begin{tabular}{|c|c|c|c|c|c|c|}
\hline $\begin{array}{l}\text { Information processes } \\
\text { Information technologies }\end{array}$ & : & 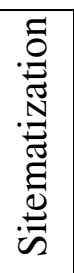 & 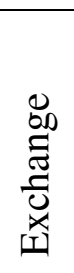 & 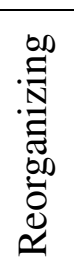 & $\begin{array}{l}\stackrel{\infty}{0} \\
: \\
0 \\
0 \\
0 \\
0 \\
0 \\
0\end{array}$ & $\begin{array}{c}\text { Usage for } \\
\text { management and } \\
\text { decison-making }\end{array}$ \\
\hline Object & & 1 & & 1 & & \\
\hline Hypermedia & 1 & & 1 & & & \\
\hline $\begin{array}{l}\text { Strategically oriented } \\
\text { information education }\end{array}$ & 1 & 1 & 1 & 1 & 1 & 1 \\
\hline Fast application development & 1 & 1 & 1 & 1 & 1 & 1 \\
\hline $\begin{array}{l}\text { Executive information } \\
\text { systems and system for } \\
\text { decision-making support }\end{array}$ & & & & & 1 & 1 \\
\hline $\begin{array}{l}\text { Computer-supported } \\
\text { methods of information } \\
\text { system development }\end{array}$ & 1 & 1 & 1 & 1 & 1 & 1 \\
\hline $\begin{array}{l}\text { Computer-supported } \\
\text { optimizaton methods }\end{array}$ & & & & & 1 & 1 \\
\hline
\end{tabular}

Table 3. Factors of business reengineering from the logistics system information process point of view. 
and flexible manner. The promptnes, flexibility and undertaking, along with the capability of anticipation of changes within the logistics environment and reciprocal adaptation, are foundational requirements of successful and efficient functioning of information organisation (1; 119-120).

\section{Mathematical Model of Critical Factors Influence of Information Technology Development to Logistics System Business Reengineering}

Processes within system are influenced by management, i.e. by targeted activity to system variables, in order to transfer from one to another condition. Commenced processes determine the behaviour of the system. Management and regulation of the process in the system should provide necessary or requested behaviour within system in accordance to the targeted goals. The purpose of mathematical model is generating guidelines of information technology development in function of business reengineering of logistics system. Mathematical model should define the factors of information technology development that have the strongest influence to business reengineering and their influence model.

Mathematical model represents the synergy effect of information technology to business reengineering. Scale and evaluation of the information technologies synergy influence to logistics system functioning could be defined from the relevant mathematical model point of view.

There is a possibility to define two-level scale $(2,4)$ or more complex multilevel scale of synergy influence (from 2 to $n$ ). The evaluation of synergy influence is determined on the basis of the position and functioning of the factors in information technology factors system structure. " 1 " defines synergy influence of information technology to business reengineering of logistics system - "4".

$$
\begin{gathered}
S=\prod_{i=1}^{n} \log A_{i} \\
A=(a, b)
\end{gathered}
$$

$$
\begin{gathered}
S_{\max }=\left(\log _{2} b\right)^{n} \\
U=\prod_{i=1}^{n} \log A_{i} / \log _{2} b^{n}
\end{gathered}
$$

Legend of terms 1.-4.

$S$ - total synergy influence value

$A_{1} \quad$ - synergie value of each information technology factor

$(a, b)$ - value domain (scale) of synergie value

$S_{\max }$ - maximum synergie value

$U-$ coefficient of synergie influence

$n$ - number of factors

Formulas show that the synergy influence of information technology is estimated by dual logarithm. From term "1." it is obvious that the synergy value of information technology influence to business reengineering of logistics system is calculated as product of multiplication of synergy values of each information technology factor. Term " 2 ." shows the synergy value domain of information technology development factor.

This model defines synergy values of 2 to 5 factors. Value " 2 ." defines that there is no synergy influence. Value "3" defines synergy value on the level of each factor separately. Value " 4 " defines partial synergy effect between the factors. Value "5" defines full synergy effect.

Term "3." shows that maximum synergy value of the information technology is $\left(\log _{2} b\right)^{n}$. Maximum synergie value is defined by calculation function of synergie coefficient (term "4"). Synergie coefficient is defined for the purpose of possible comparision of synegie influence of information technology to dynamc optimization of logistics systems from the different logistics systems and development periods point of view. Value " 1 " is maximum value of synergie coefficient and defines maximum synergie effect of information technology to business reengineering of logstics system.

Table 4 shows positioning of information technology development factors according to the functional areas of information technology and development periods. 


\begin{tabular}{|c|c|c|c|c|}
\hline & \multirow[b]{2}{*}{$\begin{array}{l}\text { Synergie influence according to periods } \\
\text { Information technolgoy development factors }\end{array}$} & \multicolumn{3}{|c|}{ Periods } \\
\hline & & 1 & 2 & 3 \\
\hline Information infrastructure & $\begin{array}{l}\text { Reactive information infrastructure } \\
\text { Distributed systems }\end{array}$ & $\begin{array}{l}3 \\
3\end{array}$ & $\begin{array}{l}5 \\
4\end{array}$ & $\begin{array}{l}5 \\
5\end{array}$ \\
\hline Communication software & $\begin{array}{l}\text { Expanded hypermedia languages and } \\
\text { visual network applications } \\
\text { Hypermedia languages and EDIFACT }\end{array}$ & $\begin{array}{c}\mathrm{N} \\
3\end{array}$ & $\begin{array}{l}\mathrm{N} \\
4\end{array}$ & $\begin{array}{l}5 \\
Z\end{array}$ \\
\hline Applicative software & $\begin{array}{l}\text { Application development on life cyclus principal } \\
\text { Application development on prototype principal }\end{array}$ & $\begin{array}{l}2 \\
\mathrm{~N}\end{array}$ & $\begin{array}{l}3 \\
\mathrm{~N}\end{array}$ & $\begin{array}{l}4 \\
4\end{array}$ \\
\hline $\begin{array}{l}\text { Methods of conceptual } \\
\text { modeling }\end{array}$ & $\begin{array}{l}\text { Object methods } \\
\text { CASE technology }\end{array}$ & $\begin{array}{l}\mathrm{N} \\
2\end{array}$ & $\begin{array}{l}\mathrm{N} \\
3\end{array}$ & $\begin{array}{l}3 \\
Z\end{array}$ \\
\hline Optimization methods & $\begin{array}{l}\text { Computer-integrated tools of econometric } \\
\text { engineering } \\
\text { Purpose applications of mathematical } \\
\text { and statistical analysis }\end{array}$ & $\begin{array}{l}\mathrm{N} \\
3\end{array}$ & $\begin{array}{l}\mathrm{N} \\
4\end{array}$ & $\begin{array}{l}5 \\
\mathrm{P}\end{array}$ \\
\hline $\begin{array}{l}\text { Methods of strategic information } \\
\text { system development }\end{array}$ & $\begin{array}{l}\text { Business reengineering } \\
\text { Business planning }\end{array}$ & $\begin{array}{l}\mathrm{N} \\
3\end{array}$ & $\begin{array}{l}4 \\
\mathrm{Z}\end{array}$ & $\begin{array}{l}5 \\
\mathrm{P}\end{array}$ \\
\hline Human resources & $\begin{array}{l}\text { Strategically oriented information education } \\
\text { Systems for decision-making and executive } \\
\text { information systems support }\end{array}$ & $\begin{array}{l}\mathrm{N} \\
3\end{array}$ & $\begin{array}{l}3 \\
3\end{array}$ & $\begin{array}{l}5 \\
4\end{array}$ \\
\hline
\end{tabular}

Table 4. Positioning of information technology development factors according to the functional areas of information technology and development periods.

In Table 4 factors of information technology development are systematized according to functional areas of informaton technology. For each functional area two factors are defined: first stated factor on higher level of development and second one (under) stated on the lower level of development. First factor can replace the second factor, or it can be a supplement to the same.

Value " $\mathrm{N}$ " in the first and second period relate to the factor that does not appear in those development periods. Value " $Z$ " in third development period refers to the factor that functioned earlier, but from the point of view of influence to the business reengineering, it has been replaced with the factor of the same functional area that will be a supplement to the same. Value "P" refers to the factor that was critical for the business reengineering in the earlier period. In the new period, it has not been replaced but used as a support to new factor appearing at higher level of development. Value " 2 " refers that there is no synergy effect. Value "4" refers to partial synergy effect between factors. Value " 5 " describes complete synergy effect. For each development period critical factors are implemented to formula.

Basing upon the data in table 5 and formula from term "1.-4." it is possible to calculate synergy effect of information technology development factors for each development period and to compare them. The formula should contain factors that have values of $2,3,4$, and 5 .

Sinergy effect calculation - I development period:

$$
\begin{aligned}
S(1)= & \log _{2} 3 * \log _{2} 2 * \log _{2} 2 * \log _{2} 3 \\
& * \log _{2} 3 * \log _{2} 3=6.31 \mathrm{bita} \\
S(\max )= & \left(\log _{2} 5\right)^{n}=\left(\log _{2} 5\right)^{6}=156.71 \mathrm{bit} \\
U(1)= & S(1) / S(\max )=6.31 / 156.71=0.04 \\
S(1)= & 6.31 \mathrm{bita} \\
U(1)= & 0.04 .
\end{aligned}
$$


Sinergy effect calculation - II development period:

$$
\begin{aligned}
S(2)= & \log _{2} 4 * \log _{2} 3 * \log _{2} 3 * \log _{2} 4 \\
& * \log _{2} 4 * \log _{2} 3 * \log _{2} 3=50.5 \text { bita } \\
S(\max )= & \left(\log _{2} 5\right)^{n}=\left(\log _{2} 5\right)^{7}=363.87 \\
U(2)= & S(1) / S(\max )=50.5 / 363.87=0.14 \\
S(2)= & 50.5 \text { bita } \\
U(2)= & 0.14 .
\end{aligned}
$$

Sinergy effect calculation - III development period:

$$
\begin{aligned}
S(3)= & \log _{2} 5 * \log _{2} 4 * \log _{2} 3 * \log _{2} 5 * \\
& \log _{2} 5 * \log _{2} 5 * \log _{2} 4=184.28 \text { bita } \\
S(\max )= & \left(\log _{2} 5\right)^{n}=\left(\log _{2} 5\right)^{7}=363.87 \\
U(3)= & S(1) / S(\max )=184.28 / 363.87=0.5 \\
S(3)= & 184.28 \text { bita } \\
U(3)= & 0.5 .
\end{aligned}
$$

As calculated, there is a very small value of the synergy effect in the first period. In the second period the value of the synergy influence is significantly higher, while the value of synergy coefficient shows small synergy effect. Third period describes complete synergy effect of information technologies. Table 4. shows that there are new information technologies on a higher level of development in the third period that enables complete synergy effect to business reengineering.

\section{Conclusion}

Logistics supply chains (as well as the wider concept of physical distribution and business logistics), ensure, by planning, analysing and controlling the fundamental flows in logistics chain (products, information and money), effective transfer of inputs (raw-materials, semiproducts, equipment), to final product and their distribution to consumers (with numerous additional services that ensure additional value to products). Although they do not represent the last invention of the last decade of $20^{\text {th }}$ century, its full affirmation, growth and development are being experienced just lately, when the business undertaking has a chance to gain as much as possible business effectiveness through expenses savings, i.e. through superior services of delivery, and to add value to the product in the mind of potential consumers and therefore significantly commit to business effectiveness and competitiveness.

Computer-supported methods for quality management continuously contribute improvement of the business processes, while methods of business reengineering redesign the existing processes to most effective ways and find new processes that contribute with new value. Computer supported methods of business reengineering are integrated with communication technologies (expanded hypermedia languages and visual network programming) and methods of conceptual modelling (object technologies). Integration of stated components enables spreading of information technology usage from segment of quantitative analysis towards segments of modelling ( systematization of data) and communicating (data exchange) that provides foundation assumptions for business reengineering of logistics system.

Dynamical and variable conditions of logistics business with growing competition, with more demanding consignees and more and more reduced provisions, require qualitative, economical, flexible and integral application solutions where the consignee is in the centre of transporttrading system. The capability of proactive and efficient response to changes is based on business reengineering and makes possible using the opportunities and elimination of danger, that continually and intensively show in dynamical and complex logistics environment.

The key feature of successful reengineering is informatization of logistics system based upon the continuous, synergy and timely implementation and usage of information technology components within the logistics processes. Taking into consideration that processes can completely influence informatization of successfulness and efficiency of reengineering, logistics processes support directly depends upon the quality of computer applications. During the informatization of the logistics system it is necessary to compare and synergetically develop fundamental components of the quality informatization. Technological component, which is, based 
on development maintenance of information infrastructure of logistics system in accordance to the development of modern information technologies, and functional component that represents the intensity, success and efficiency of development and usage of computer applications in cases of management and performance of logistics processes.

Mathematical model enables quantification of the information technology development influence to dynamic optimisation of logistics system on level of each factor separately and in groups on factor system level. Results show that significantly stronger synergy influence of information technology in third development period opposite to previous two periods. Based upon results, it is to be concluded that information technology development factors defined in third (current) development period of year 2000 provide foundation assumptions for business reengineering of logistics system at all levels - operative, tactical, strategic and the one between companies.

Information technology development is proportionate to synergy between functional components of information technology - communication technologies, applicative programmes, information infrastructure and human potentials. Synergy effect of information technology components produces stronger synergy effect of foundation information processes of gathering, systematization, processing and data and information exchange. Considering the fact that stated processes and foundation processes of logistics system and for comparison of information of logistics system effect to business reengineering in different development periods it is to be concluded that strengthening of synergy of information technology development factors are proportionally supported by intensity development and scope of business reengineering spreading within logistics system as well as strengthening of synergy of logistics system effects.

While designing the methodological scope of business reengineering of logistics system it is necessary to systematize critical development factors and relation intensity inside and between the groups of defined factors. The strongest relations represent guidelines for defining method- ological scope. Methods of business reengineering are based upon object technologies and integration of modern information technologies that provide analyses and anticipation of changes of goods flow and flexible reaction to those changes.

\section{References}

[1] Brown, C., V., ToPI, H., IS Management Handbook, Auerbach, Publications, USA, 2000.

[2] Coyle, Bardy, Langley, The Management of Business Logistics, West Publishing Company, USA, 1992.

[3] ČIČIN-ŠAIN, M., VUKMIROVIĆ, S., ČAPKO Z., Methodological framework for informatization development in inter-organizational systems, Papers and Studies of the Faculty of Economics in Rijeka, Journal of Economic Theory and Practice, Rijeka, 2001., pp. 215-234,

[4] Fingar, P., Stikeleather, J., Distributed object for business: Getting started with the next generation of computing, SIGS Publications, Inc., New York, USA, 1996., http: //biz.idbsu.edu/is/ is $497 \mathrm{op} / \mathrm{f}$ ingar.htm.

[5] Hammer, M., Champy, J., Company Reorganization: Revolution Manifest in Business (translation), Economic Gazette, Ljubljana, 1995.

[6] HerleA, D., LAM, S., Wu, M., Structured and Object-Oriented Analysis and Design, Software Engineering, Course Project Report, 1997. http: //www. cpsc.ucalgary.ca/ danah/613/ prez/new/report.html.

[7] MCLEOD, R. JR., SCHELL, G., Management Information Systems, Prentice Hall, Upper Saddle River, New Jersey, USA, 2001.

[8] PAVLIĆ, M., Information Systems Development, Znak, Zagreb, 1997.

[9] Stojiljković, N., Business Process Reengineering: Fundamental Task, Infotrend, br. 47, Zagreb, june, 1996., pp. 39-44.

[10] Strahonja, V., PaVlić, M., Varga, M., Information Systems Planning, INA INFO, Zagreb, 1992.

[11] VUKMIROVIĆ, S., Impact of Information Technology on Organizational Structuring of Freight Forwarding Company, Ph.D. thesis, Fakulty of Organization and Informatics, Varaždin, 1999. 
Received: June, 2004

Accepted: June, 2004

Contact address:

Marina Čičin-Šain

Slavomir Vukmirovic

Zvonko Čapko

Faculty of Economics and Business Administation Rijeka

University of Rijeka

Ivana Filipovića 4

51000 Rijeka

Croatia

MARINA ČIČIN-ŠAIN, Ph.D. is a full professor at the Faculty of Economics, University of Rijeka, Croatia, where she has been head of the Informatics Department since 2000. She graduated from the Faculty of Science (PMF) in Zagreb. Before she became a university teacher, she had spent some ten years working as a computer programmer and an IBM system engineer in INA Institute. She has published over one hundred scientific and professional papers.

SLAVOMIR VuKMIROVIĆ, Ph.D. is an assistant professor at the Faculty of Economics, University of Rijeka, Croatia. He graduated from the Faculty of Organization and Informatics in Varždin. He has published over thirty scientific and professional papers.

ZVONKO ČAPKO, Ph.D. is a senior assistant at the Faculty of Economics, University of Rijeka, Croatia. He graduated from the same faculty. So far, he has published over ten scientific and professional papers. 